\title{
Reverse Transcriptase
}

National Cancer Institute

\section{Source}

National Cancer Institute. Reverse Transcriptase. NCI Thesaurus. Code C17096.

An RNA-dependent DNA polymerase that is involved in the replication of retroviruses an

in the maintenance of telomeres. 